\title{
MicroRNA Gene
}

National Cancer Institute

\section{Source}

National Cancer Institute. MicroRNA Gene. NCI Thesaurus. Code C80699.

A gene that encodes a microRNA, which participates in the regulation of gene expression. 